\title{
Antiinflammatory Activity of Heat-treated Cassia alata Leaf Extract and Its Flavonoid Glycoside
}

\author{
Hiroyoshi MORIYAmA, ${ }^{*, a}$ Tohru IIZUKA, ${ }^{a}$ Masahiro NAGAI, ${ }^{a}$ \\ Hideki MiYATAKa, ${ }^{b}$ and Toshio SATOH ${ }^{b}$ \\ Faculty of Pharmaceutical Sciences, Hoshi University, ${ }^{a}$ 2-4-41 Ebara, Shinagawa-ku, \\ Tokyo 142-8501, Japan and Faculty of Pharmaceutical Sciences, Tokushima \\ Bunri University, ${ }^{b}$ Tokushima 770-8514, Japan
}

(Received October 3, 2002; Accepted March 14, 2003)

\begin{abstract}
Antiinflammatory activities of heat-treated Cassia alata leaf extract and kaempferol 3-O-gentiobioside(K3G) isolated from $C$. alata as an abundant flavonoid glycoside were studied by comparing their activities with the activities of sun-dried $C$. alata leaf extract. We observed strong inhibitory effects on Concanavalin A-induced histamine release from rat peritoneal exudate cells both in the extracts of heat-treated and sun-dried $C$. alata leaves. Furthermore, the heattreated leaf extract exhibited stronger inhibitory effects than the effects of the sun-dried leaf extract at low concentrations in the studies of Concanavalin A-induced histamine release, 5-lipoxygenase inhibition, and also inhibition of cyclooxygenases (COX-1 and COX-2), whereas K3G showed weak inhibitory effects on Concanavalin A-induced histamine release, 5-lipoxygenase, and COX-1. No anti-hyaluronidase effect was detected in any of the materials tested.
\end{abstract}

Key words_-Cassia alata; kaempferol gentiobioside; antiinflammatory activity; cyclooxygenase; 5-lipoxygenase; histamine release

\section{INTRODUCTION}

Cassia alata L. (Leguminosae) is a native of tropical America now grown in Indonesia, where it is often found in the wild. C. alata leaf extract has been reported to have various pharmacological activities, including antiinflammatory activities using carrageenan-induced edema methods, ${ }^{1-3)}$ the cotton implantation method, ${ }^{1)}$ and an assay for inhibitory effects on compound 48/80-induced histamine release $^{2)}$; analgesic activity, ${ }^{4}$ laxative activity, ${ }^{5,6)}$ and antiplatelet-aggregating activity. ${ }^{7)}$

Heat treatment of fresh $C$. alata leaf was effective in stabilizing kaempferol 3-O-gentiobioside (K3G), which was found abundantly in $C$. alata leaf, as previously reported. ${ }^{8)}$ Consequently, it is meaningful to study the biological significance, such as antiinflammatory activities, of K3G. Various flavonoid glycosides are known to have antiinflammatory activities. ${ }^{9)}$

In the present study, we have investigated the extracts of C. alata leaves in addition to $\mathrm{K} 3 \mathrm{G}$ isolated from $C$. alata leaf ${ }^{8)}$ as shown in Fig. 1 for further elaboration of their antiinflammatory effects, including the inhibitory effect on histamine release from rat peritoneal exudate cells induced by Concanavalin A

e-mail: fwkp3841@mb.infowwb.ne.jp

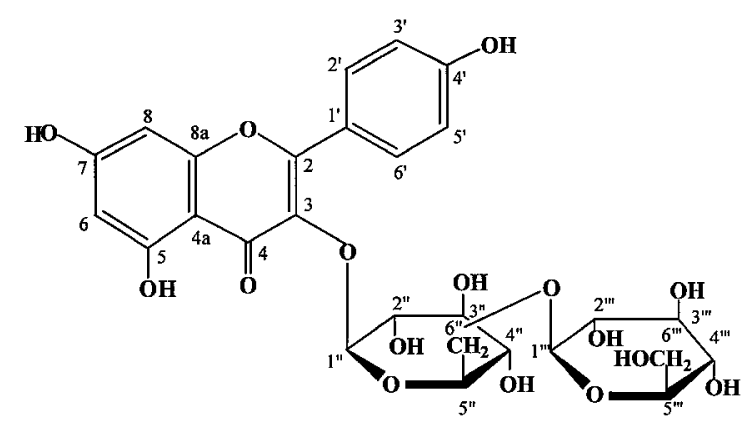

Fig. 1. Structure of Kaempferol 3-O-gentiobioside (K3G)

and on enzymes such as cyclooxygenases (COX-1 and COX-2), 5-lipoxygenase, and hyaluronidase. Their effects were compared with those of the sun-dried $C$. alata leaf extract as a reference, of which the inhibitory effects were previously reported to be useful for evaluating antiinflammatory activities. ${ }^{10-16)}$

\section{MATERIALS AND METHODS}

Plant Materials All the plant materials (C. alata leaves) used in the experiments were obtained from PT Haldin Pacific Semesta (Jakarta, Indonesia). $C$. alata was grown in a region $80 \mathrm{~km}$ southeast of Jakarta. Leaflets with sizes ranging from 5 to $9 \mathrm{~cm}$ in width and from 10 to $16 \mathrm{~cm}$ in length were harvested in January 2000. They were stored in plastic bags at 
room temperature and were used for the present study within 3 months. Heat-treated and sun-dried leaves were prepared as previously described. ${ }^{8)}$

Preparation of Plant Extracts Twenty grams of each of pulverized heat-treated and sun-dried C. alata leaves were extracted with $1000 \mathrm{ml}$ of distilled water in a water bath at $80^{\circ} \mathrm{C}$ for $1 \mathrm{~h}$. After filtration, the extracts were evaporated under reduced pressure and lyophilized. The yields were $18.6 \%$ and $19.9 \%$, respectively.

\section{Isolation of Kaempferol 3-O-Gentiobioside}

Isolation of $\mathrm{K} 3 \mathrm{G}$ was achieved using a preparatory HPLC column as described previously. ${ }^{8)}$ Purity was confirmed to be $99 \%$ with HPLC.

Chemicals Concanavalin A and phosphatidylL-serine were purchased from Sigma Chemical (St. Louis, MO, USA), $\left[1-{ }^{14} \mathrm{C}\right]$ arachidonic acid was from Amersham American Biosciences Corp. (Piscataway, NJ, USA), and trichloroacetic acid was obtained from Wako Pure Chemical Industry (Japan). RPMI-1640 was obtained from Dainippon Pharmaceutical Co., Ltd. (Japan). HEPES was purchased from Dojindo Laboratories (Japan). COX-1 and COX-2 were obtained from Cayman Chemical Company (Ann Arbor, MI, USA). Unless otherwise specified, all other reagents were of analytical grade.

Animals Male Wistar rats $(300-500 \mathrm{~g})$ were raised as described previously. ${ }^{12)}$

Isolation of Rat Peritoneal Mast Cells Male Wistar rats were exsanguinated and injected intraperitoneally with $15 \mathrm{ml}$ of physiological salt solution (PSS) consisting of $137 \mathrm{~mm} \mathrm{NaCl}, 2.7 \mathrm{mM} \mathrm{KCl}, 1$ $\mathrm{mM} \mathrm{MgCl}_{2}, 1.6 \mathrm{mM} \mathrm{CaCl}_{2}, 10 \mathrm{mM}$ HEPES, $0.05 \%$ gelatin, and $0.41 \mathrm{mM} \mathrm{NaH} \mathrm{PO}_{4}$ in distilled water at $\mathrm{pH}$ 7.4. The abdominal region was gently massaged for $1.5 \mathrm{~min}$ and then the peritoneal exudate cells were collected in a polystyrene tube. The cell suspensions were centrifuged at $265 \times \mathrm{g}$ for $15 \mathrm{~min}$ at $4^{\circ} \mathrm{C}$ and washed several times with the physiological suspension.

\section{Assay of Histamine Release from Rat Peritoneal} Exudate Cells Induced by Concanavalin A A 0.05 $\mathrm{ml}$ aliquot of varying concentrations of the extracts dissolved in dimethylsulfoxide (DMSO) was mixed with $1.75 \mathrm{ml}$ of the aforementioned physiological solution to which $5.6 \mathrm{mM}$ glucose and phosphatidyl-Lserine $30 \mu \mathrm{g} / \mathrm{ml}$ (PSS + glucose) were added. The mixed solution was preincubated at $37^{\circ} \mathrm{C}$ for $5 \mathrm{~min}$, $0.05 \mathrm{ml}$ of peritoneal exudate cell suspension was ad- ded, and the mixture was incubated at $37^{\circ} \mathrm{C}$ for 15 $\min$. The test sample was replaced with PSS + glucose as a control. The preincubated peritoneal cell suspension was mixed with $0.2 \mathrm{ml}$ of Concanavalin A $(4.0 \times$ $10^{-4} \mathrm{~g} / \mathrm{ml}$ ) solution and incubated at $37^{\circ} \mathrm{C}$ for 10 $\mathrm{min}$. The physiological solution was added in place of Concanavalin A solution as a blank. The mixture was cooled to $4^{\circ} \mathrm{C}$ and centrifuged at $300 \times \mathrm{g}$ for $10 \mathrm{~min}$ at this temperature. Histamine in the supernatant and residue was measured according to a previously reported method. ${ }^{13,17)}$ The percent inhibition was expressed as follows:

$$
\text { Histamine release }(\%)=\frac{\mathrm{Ps}}{\mathrm{Ps}+\mathrm{Pr}} \times 100=\mathrm{A}
$$

where Ps is histamine in supernatant and $\mathrm{Pr}$ is residue histamine in cells.

$$
\text { Inhibition }(\%)=\left(1-\frac{\mathrm{S}-\mathrm{B}}{\mathrm{C}-\mathrm{B}}\right) \times 100
$$

where $\mathrm{S}$ is $\mathrm{A}$ obtained from the test sample, $\mathrm{C}$ is $\mathrm{A}$ obtained from the control, and B is A obtained from the blank.

Assay for COX-1 and COX-2 Inhibition A modification of the method of Futaki et al ${ }^{10)}$ was used. COX-1 and COX-2 enzymes were isolated and purified from ram seminal vesicles and sheep placenta, respectively. A mixture of Tris- $\mathrm{HCl}$ buffer $10 \mu \mathrm{l}$ $(100 \mathrm{mM})$, hematin $10 \mu \mathrm{l}(1 \mu \mathrm{M})$, phenol $10 \mu \mathrm{l}$ (2 $\mathrm{mM}$ ), and $50 \mu \mathrm{l}$ of distilled water was added to $10 \mu \mathrm{l}$ of test materials dissolved in 1\% DMSO. Then $200 \mathrm{U}$ of COX-1 or COX-2 was added to the mixture. The reaction medium was preincubated with each of the extract samples for $2 \mathrm{~min}$ at $37^{\circ} \mathrm{C}$, and then $2 \mu \mathrm{l}$ of $51.4 \mu \mathrm{M}\left[1-{ }^{14} \mathrm{C}\right]$ arachidonic acid was added and incubated for $2 \mathrm{~min}$ at $37^{\circ} \mathrm{C}$. After terminating the reaction in an ice bath, $0.4 \mathrm{ml}$ of $n$-hexane/ethyl acetate $(2: 1, \mathrm{v} / \mathrm{v})$ was added to the reaction mixtures and the mixtures were centrifuged at $2000 \times \mathrm{g}$ for $1 \mathrm{~min}$ at room temperature. The aqueous phase was kept and the organic solvent phase was discarded. The extraction procedure was repeated twice and then $50 \mu \mathrm{l}$ of ethanol was added to the aqueous phase and the mixtures were centrifuged at $2000 \times \mathrm{g}$ for $1 \mathrm{~min}$ at room temperature. The amount of radioactivity in the supernatant was measured using a scintillation counter.

The inhibitory rate (\%) of COX activities was expressed as follows:

Inhibition rate (\%)

$$
=\left(1-\frac{\mathrm{RA}(\text { sample })-\mathrm{RA}(\text { blank })}{\mathrm{RA}(\text { control })-\mathrm{RA}(\text { blank })}\right) \times 100
$$


where RA is radioactivity (cpm).

Assay for 5-Lipoxygenase Inhibition The previously reported method was used ${ }^{11,16)}$ with slight modifications. Briefly, rat basophilic leukemia-1 (RBL-1) cells were grown in RPMI-1640 medium containing $10 \%$ heat-inactivated newborn calf serum (NCS), penicillin 100 units $/ \mathrm{ml}$, and streptomycin 100 $\mathrm{mg} / \mathrm{ml}$. Cells were cultured at $37^{\circ} \mathrm{C}$ in $5 \% \mathrm{CO}_{2} /$ air. Cells in the growth phase were collected by centrifuging at $100 \times \mathrm{g}$ for $5 \mathrm{~min}$ and suspended at a density of $3 \times 10^{7}$ cells $/ \mathrm{ml}$ in $50 \mathrm{mM}$ phosphate buffer $(0.25 \mathrm{M}$ sucrose, $1 \mathrm{mM}$ EDTA, $2 \mathrm{~mm}$ glutathione, pH 7.4). The RBL-1 cells containing 5-lipoxygenase were stored at $-80^{\circ} \mathrm{C}$ until use. The assay system $(0.5 \mathrm{ml})$ consisted of $50 \mathrm{mM}$ of the aforementioned phosphate buffer, varying concentrations of the samples in 1\% DMSO, $2 \mathrm{mM} \mathrm{CaCl}_{2}, 0.2 \mathrm{mg} / \mathrm{ml}$ of arachidonic acid $(10 \mathrm{mg} / \mathrm{ml} \mathrm{MeOH}, 10 \mu \mathrm{l})$, and ultrasonic pressed RBL- 1 cell $\left(1 \times 10^{7}\right.$ cells $\left./ \mathrm{ml}\right)$ in a final volume of 0.5 $\mathrm{ml}$. Reaction mixtures were incubated at $37^{\circ} \mathrm{C}$ for 3 $\mathrm{min}$, and the reaction was terminated with the addition of methanol $(0.5 \mathrm{ml})$. The mixtures were centrifuged and then 5-HETE in the supernatant was analyzed by HPLC as performed previously. ${ }^{11)}$

Assay for Anti-Hyaluronidase Activity Hyaluronidase activity was determined according to the method described previously. ${ }^{15)}$

Statistical Analysis Statistical comparisons were performed by Bonferroni's multiple $t$-test. A $p$ value $<0.05$ was considered statistically significant.

\section{RESULTS AND DISCUSSION}

The heat-treated and sun-dried C. alata leaf extracts and $\mathrm{K} 3 \mathrm{G}$ isolated from $C$. alata leaf were found to have various antiinflammatory activities. Among them, the inhibitory effects on the histamine release induced by Concanavalin A were notable in the extracts of heat-treated and sun-dried $C$. alata leaves, exhibiting a concentration dependence as shown in Table 1. K3G also inhibited the histamine release in a concentration-dependent manner, although the extent of the inhibition was less than that by the leaf extracts. The result using sun-dried C. alata leaf extract was in agreement with that of a previous study'); however, the extent of inhibition was more potent than the extract of the previously investigated plant material ${ }^{2)}$ even when using low concentrations of our leaf extracts. Although reason for the difference in the results is not clear, it may have been due to the use of
Table 1. Inhibitory Effects on Concanavalin A-Induced Histamine Release from Rat Peritoneal Exudate Cells

\begin{tabular}{ccc}
\hline \hline Material & Conc. $(\mathrm{mg} / \mathrm{ml})$ & Inhibition $(\%)$ \\
\hline CA & 0.01 & $0.5 \pm 0.8$ \\
& 0.10 & $71.0 \pm 3.7$ \\
HCA & 1.00 & $96.7 \pm 0.9$ \\
& 0.01 & $3.4 \pm 0.2$ \\
& 0.10 & $95.0 \pm 1.4^{b)}$ \\
K3G & 1.00 & $98.4 \pm 0.5$ \\
& 0.01 & $-0.4 \pm 2.9^{a)}$ \\
& 0.10 & $8.1 \pm 1.3^{b)}$ \\
& 1.00 & $32.8 \pm 4.2^{c)}$ \\
\hline
\end{tabular}

CA: sun-dried $C$. alata leaf, HCA: heat-treated $C$. alata leaf, K3G: kaempferol 3-O-gentiobioside. $n=3, \pm$ SE.

$a), b), c)$ Statistical significance at $p<0.05$ when compared with CA.

Table 2. Inhibitory Effects on COX-1 and COX-2

\begin{tabular}{cccc}
\hline \hline \multirow{2}{*}{ Material } & Conc. $(\mathrm{mg} / \mathrm{ml})$ & \multicolumn{2}{c}{ Inhibition (\%) } \\
\cline { 3 - 4 } & & COX-1 & COX-2 \\
\hline \multirow{2}{*}{ CA } & 0.03 & $5.7 \pm 5.2$ & $-6.1 \pm 1.5$ \\
& 0.10 & $30.0 \pm 9.5$ & $-0.4 \pm 2.1$ \\
& 0.30 & $86.6 \pm 1.7$ & $28.0 \pm 4.0$ \\
& 1.00 & $100.5 \pm 0.7$ & $72.9 \pm 1.3$ \\
HCA & 0.03 & $9.8 \pm 6.0$ & $15.5 \pm 4.3^{a)}$ \\
& 0.10 & $42.2 \pm 6.2$ & $32.5 \pm 18.0^{b)}$ \\
& 0.30 & $92.5 \pm 1.1^{c)}$ & $57.4 \pm 5.8^{c}$ \\
K3G & 1.00 & $96.6 \pm 2.0^{d)}$ & $84.6 \pm 3.5^{d)}$ \\
& 0.03 & $5.2 \pm 4.0$ & $4.7 \pm 3.4^{a)}$ \\
& 0.10 & $-0.2 \pm 7.6^{b)}$ & $7.0 \pm 3.7$ \\
& 0.30 & $13.5 \pm 3.0^{c)}$ & $12.9 \pm 2.6^{c)}$ \\
& 1.00 & $37.3 \pm 0.7^{d)}$ & $14.0 \pm 2.6^{d)}$ \\
\hline
\end{tabular}

CA: sun-dried $C$. alata leaf, HCA: heat-treated $C$. alata leaf, K3G: kaempferol 3-O-gentiobioside. $n=3, \pm \mathrm{SE}$.

$a), b), c), d)$ Statistical significance of difference at $p<0.05$ when compared with CA.

a different histamine releaser in the experiment. Compound 48/80 and Concanavalin A as histamine releasers were reported to give a difference in the inhibitory rate. ${ }^{12)}$

Table 2 shows the results of the inhibitory effects on COX-1 and COX-2 activities. Extracts of both heattreated and sun-dried C. alata leaves demonstrated strong inhibitory effects, whereas K3G exhibited weak inhibitory effects on COX-1 and had little or no effect on COX-2. When the inhibitory effect of heat-treated leaf extract was compared with that of sun-dried leaf extract, the heat-treated leaf extract showed stronger inhibitory effects than the sun-dried leaf extract, with 
Table 3. Inhibitory Effects on 5-Lipoxygenase

\begin{tabular}{ccc}
\hline \hline Material & Conc. $(\mathrm{mg} / \mathrm{ml})$ & Inhibition $(\%)$ \\
\hline CA & 0.01 & $-3.2 \pm 8.9$ \\
& 0.10 & $64.9 \pm 1.0$ \\
HCA & 1.00 & $98.0 \pm 0.1$ \\
& 0.01 & $26.9 \pm 3.1^{a)}$ \\
& 0.10 & $84.1 \pm 0.8^{b)}$ \\
K3G & 1.00 & $99.2 \pm 0.1$ \\
& 0.01 & $3.9 \pm 2.6$ \\
& 0.10 & $3.6 \pm 2.6^{b)}$ \\
& 1.00 & $10.2 \pm 1.0^{c)}$ \\
\hline
\end{tabular}

CA: sun-dried $C$. alata leaf, HCA: heat-treated $C$. alata leaf, K3G: kaempferol 3-O-gentiobioside. $n=3, \pm \mathrm{SE}$.

$a), b), c)$ Statistical significance of difference at $p<0.05$ when compared with CA.

significant differences in COX-1 at $0.30 \mathrm{mg} / \mathrm{ml}$ and in $\mathrm{COX}-2$ at all concentrations tested.

COX-1 plays an important role in prostaglandins and thromboxane $\mathrm{A}_{2}$ synthesis. The inhibitory effect of $C$. alata leaf extract on the enzyme explains the result of our previous study on the antiplatelet aggregating activity of the leaf extract using the same plant, with strong inhibitory effects on the platelet aggregation induced by ADP or collagen as an aggregating agent. ${ }^{7)}$ Consequently, the extract inhibited the development of small-sized platelet aggregates into large-sized platelet aggregates.

The inhibitory effects on 5-lipoxygenase are shown in Table 3. We confirmed that the extracts of heattreated and sun-dried $C$. alata leaves have strong inhibitory effects, which were particularly significant for the heat-treated leaf extract at low concentrations $(0.01$ and $0.10 \mathrm{mg} / \mathrm{ml})$. We also observed that $\mathrm{K} 3 \mathrm{G}$ had little inhibitory effect on 5-lipoxygenase activity.

Our previous study revealed that heat treatment played an important role in stabilizing $\mathrm{K} 3 \mathrm{G}$, detecting more $\mathrm{K} 3 \mathrm{G}$ in heat-treated leaf (about $1.0 \%$, w/w dry wt.) than in sun-dried leaf (about $0.6 \%, w / w$ dry wt.) . ${ }^{8)} \mathrm{We}$ assumed that the difference in the $\mathrm{K} 3 \mathrm{G}$ concentrations between the leaves might be attributable to the presence of an enzyme(s) such as glucosidase on $\mathrm{K} 3 \mathrm{G}$. It is therefore possible that a similar stabilization or change may have occurred in other constituents in heat-treated leaf, thereby resulting in the stronger inhibitory effects of the heat-treated leaf extract on the Concanavalin A-induced histamine release, COX-1, COX-2, and 5-lipoxygenase than sun-dried leaf. Furthermore, it is apparent the stron- ger inhibitory effects of heat-treated leaf extract than those of sun-dried leaf extract may not be attributed to $\mathrm{K} 3 \mathrm{G}$, but to some other constituents stabilized by heat treatment because $\mathrm{K} 3 \mathrm{G}$ was found to have weak inhibitory effects on all the antiinflammatory activities studied.

In conclusion, we found that the extracts of heattreated and sun-dried $C$. alata leaves have strong inhibitory effects on concanavalin A-induced histamine release, COX-1 and COX-2, and 5-lipoxygenase activities, whereas $\mathrm{K} 3 \mathrm{G}$ as a major flavonoid glycoside in C. alata leaf showed weak or little inhibitory effects on the aforementioned activities. Therefore, K3G contributes little to the inhibitory effects of the heattreated and sun-dried leaf extracts. Consequently, because heat-treated leaf extract exhibited more potent inhibitory effects in some of the activities at lower concentrations than the sun-dried extract, it is assumed that the heat-treated extract may contain other constituents responsible for the stronger inhibitory effects. Furthermore, none of the tested materials showed inhibitory effects on hyaluronidase activity.

\section{ACKNOWLEDGMENT}

We are grateful to PT Haldin Pacific Semesta for supplying plant materials and We'll Corporation Group for financial support.

\section{REFERENCES}

1) Palanichamy S., Nagarajan S., Fitoterapia, 61, 44-47 (1990).

2) Ohsumi K., Ito M., Ohmori Y., Kishi M., Katada T., Riswan S., Konishi H., Nat. Med., 49, 472-474 (1995).

3) Abatan M.O., Fitoterapia, 61, 336-338 (1990).

4) Palanichamy S., Nagarajan S., J. Ethnopharmacol., 29, 73-78 (1990).

5) Elujoba A. A., Ajulo O.O., Iweibo G.O., $J$. Pharm. Biomed. Anal., 7, 1453-1457 (1989).

6) Ogunti E.O., Elujoba A. A., Fitoterapia, 64, 437-439 (1993).

7) Moriyama H., Iizuka T., Nagai M., Terazono M., Hoshi K., Nat. Med., 56, 178-183 (2002) .

8) Moriyama H., Iizuka T., Nagai M., Yakugaku Zasshi, 121, 817-820 (2001).

9) "The Flavonoids: Advances in Research since 1986," ed. by Harborne J. B., Chapman \& Hall, London, 1994, pp. 624-635. 
10) Futaki N., Takahashi S., Yokoyama M., Arai S., Higuchi S., Otomo S., Prostaglandins, 47, 55-59 (1994).

11) Sogawa S., Nihro Y ., Ueda A., Miki T., Matsumoto H., Satoh T., J. Med. Chem., 36, 3904 -3909 (1993).

12) Miyataka H., Nishiki M., Matsumoto H., Fujimoto T., Matsuka M., Isobe A., Satoh T., Biol. Pharm. Bull., 21, 723-729 (1998).

13) Kakegawa H., Matsumoto H., Satoh T., Chem. Pharm. Bull., 40, 1439-1442 (1992).
14) Kakegawa H., Matsumoto H., Sato T., Planta Med., 54, 385-389 (1988).

15) Miyataka H., Nishiki M., Matsumoto H., Fujimoto T., Matsuka M., Satoh T., Biol. Pharm. Bull., 20, 496-501 (1997).

16) Blackham A., Griffiths R. J., Hallman C., Mann J., Mitchell P. D., Norris A. A., Simpson W. T., Agents Actions, 30, 432-442 (1990).

17) Shore P. A., Barkhalter A., Cohn V. H., J. Pharmacol. Exp. Ther., 127, 182-186 (1959). 